\title{
Effect of Student Teaching of Physical Education and Sports on the Sense of Competence "Develop and Innovate"
}

\author{
Ayman Guemri1,2, Nejah Kacem³ ${ }^{3}$ Chokri Naffeti ${ }^{4}$, Liwa Masmoudi², Tarak Jebali², \\ Mourad Bahloul ${ }^{2}$ \\ ${ }^{1}$ Group for the Study of Development and Social Environment (GEDES), Sfax, Tunisia \\ ${ }^{2}$ Institute of Directors of Business of Sfax, Sfax, Tunisia \\ ${ }^{3}$ State, Culture and Change of Society, Sfax, Tunisia \\ ${ }^{4}$ Higher Institute of Sport and Physical Education of Sfax, Sfax, Tunisia \\ Email: ayman.guemriyahoo.fr
}

Received 23 February 2016; accepted 13 May 2016; published 17 May 2016

Copyright (C) 2016 by authors and Scientific Research Publishing Inc.

This work is licensed under the Creative Commons Attribution International License (CC BY).

http://creativecommons.org/licenses/by/4.0/

c) (i) Open Access

\begin{abstract}
This study is to search the effect of the teaching course of EPS on the sense of competence "develop and innovate". The French version of the questionnaire by Perrault (2008) was used to calculate these effects. Our sample consists of 402 trainees of the ISSEP of Sfax. The results show that Physical Education and Sports trainee teachers did not consider having actually made any progress during the teaching course of EPS with regard to the competency "develop and innovate". This result could be explained by the result of Blanchette (2007), which showed that teachers in the beginning of their careers tended to opt for "compliance" strategies for "survival" (Blanchette, 2007: p. 57). There are several research opportunities dealing with innovation in favor of trainee teachers in Physical Education and Sports.
\end{abstract}

\section{Keywords}

Pedagogical Internship, Feeling of Competence, Training, Innovation

\section{Introduction}

Since the independence, policymakers in Tunisia have put education a major national priority. According to Lacoste et al. (2007), "Teaching is a profession which is learned" (Lacoste, 2007: p.7). This learning of teaching is carried out by a university education (higher institutes of sport and physical education). According to Bourdoncle (2000: p. 121), a university education is "firmly articulated to professional practice and internships". All this

How to cite this paper: Guemri, A., Kacem, N., Naffeti, C., Masmoudi, L., Jebali, T., \& Bahloul, M. (2016). Effect of Student Teaching of Physical Education and Sports on the Sense of Competence "Develop and Innovate". Advances in Physical Education, 6, 116-125. http://dx.doi.org/10.4236/ape.2016.62013 
pushes several researchers in science of education to establish research in the field of educational training, in this context researchers in science of education such as, Carlier (2002), Lessard \& Bourdoncle (2002), Dugal \& Amade-Escot (2004), Bouvier (2008), Carlier (2009), Greenhouses (2009), MEN (2010), Tremblay (2013), Tremblay et al. (2015) are driven to conduct research in the field of educational training. The sense of self efficiency is among the indices to evaluate the pedagogical teaching course. Romano (1996) "considers a sense of personal effectiveness as an indicator of the effectiveness of training". Other research highlighted "correlations between efficacy and skills and suggested that the confidence of an individual to carry out a task may be induced as a result of training" (Perrault, 2010: p. 2). "Form and innovate" is a major education-enhancing competence. This competence is a more and more indispensable skill at the level of the training of teachers of different subjects, including students with physical education and sports. This skill is a transversal competence affecting exercise of professional responsibility and ethics. This study is to search the effect of the teaching course of EPS on the sense of competence "Develop and Innovate".

\subsection{Sense of Competence as an Indicator of the Quality of Training}

After any training, it is important to assess the preparation, the timing, content, etc. Indeed, there are several ways to evaluate training.

According to Gerard (2003), there are 4 levels of evaluation of the effectiveness of training as in Figure 1:

-impact assessment.

-evaluation of the adequacy.

-assessment of learning.

-evaluation of the transfer.

According to Gerard (2003), the evaluation of the achievements of the training is essential, for this reason we need an index that enables us to assess this impact. Romano (1996) considers "a sense of personal effectiveness as an indicator of the effectiveness of training". Piccoli et al. (2001) also demonstrate that "it is important to estimate the perceptions of learners in their own capacities, within the framework of the evaluation of the effectiveness of training". From these findings, we note that "sense of self efficiency has a significant effect on the nature and quality of the work of the teacher" (Rich et al., 1996: p. 374).

\subsection{Jurisdiction Develop and Innovate}

Development and innovation is the tenth skill of repository (Perrault, 2010) teacher training. This skill is a transversal competence affecting exercise of professional responsibility and ethics. And after Perrault's questionnaire (2008), this skill consists in "analyzing these business practices and identifying and engaging those who can provide assistance and support in the exercise of the profession, taking into account, while teaching, the contributions of school education researches in order to determine their needs during the professional training".

This jurisdiction is comprised of two parts: the training and innovation.

-The training aims "to update, strengthen and expand the knowledge acquired by the teacher during his initial training to acquire new skills and to assimilate certain aspects of their profession. Professional development activities may also be organized to support the implementation of a reform in education" (OECD, 2005: p. 140).

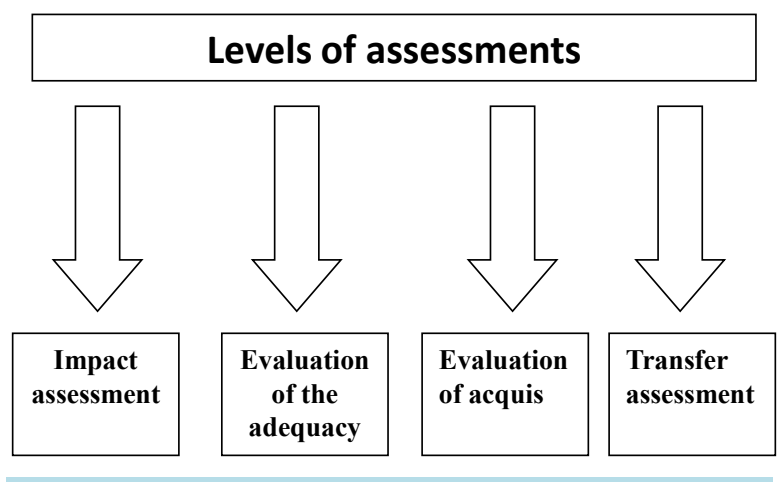

Figure 1. Diagram of the 4 levels of assessments according to Gerard (2003). 
This training is very important, it "seems to indicate that the concepts of lifelong and continuous skills development aimed to enhance learning progress throughout the teaching career". (Eurydice, 2005: p. 10).

-innovation is "a process with action of change as an intention and the introduction of an element or a system in an already structured context as a medium". (Cros, 2001: 119).

To form and to innovate, the trainee teacher must:

-update his disciplinary knowledge.

-update his didactic knowledge.

-update his pedagogical knowledge.

-know his perspective of educational policy in Tunisia.

-refresh his knowledge at the level of the contributions of research and educational innovation.

-know how to use the contributions of research in education.

-know how to operate educational innovations in education.

\subsection{The Student Teaching in EPS}

The student teaching occupies a very important place in the formation of the student in different higher institutes of sport and physical education. "Most of the trainers and trainers involved in these programs consider that closer and more meaningful linkages between the academic training and school-based training are an essential condition to achieve this intent" (Boutet et al., 2002: p. 2). In fact, the course represents "an opportunity to live a significant relationship with a mentor that can serve as a model, guide, comment on situations and interventions" (Gervais, 1999: p. 280). In the old system, the training of the master student (2 years) performs a one year internship in second grade in a primary school (DUEP), while the student training Professor (MEP) (4 years) performs a two-year internship, in the 3rd year and 4th year which are respectively: a year in a preparatory school (college), a session per week and a year in a high school, two sessions per week. Currently, in LMD (licence, master, doctorate) system, each student in the 3rd-year Bachelor EPS is supposed to take a pedagogy-oriented internship of EPS throughout a school year and they teach pupils at a preparatory or a high school and attend a weekly meeting every week during that year. This internship is provided by a commission composed:

-of an educational advisor.

-of a school coach.

-of an internship coordinator.

The action of each of these members takes place within a framework of complementarity with the aim of a comprehensive and coherent intern training. Lacoste et al. (2007) declare that the student teaching is crucial in training. According to the draft plan of studies and the system of exams (2009) relating to the: basic Bachelor of Education Physics for the fundamental licensing Education physics towards training and research of Ministry of youth, sports, the student must pass a course of preparation education. The internship of ISSEP of Sfax students takes place in preparatory and high schools in various regions of the city of Sfax on Tuesdays and Thursdays morning: from $8 \mathrm{~h}$ to $12 \mathrm{~h}$. Each student performs only a single output and chooses between these two days. Every morning two students are doing the course while one is making the observation, the other signs and vice versa according to Table 1 .

After each session, there is a discussion between the counselor and the trainee teacher to assess the session content. The framer must mention the different necessary instructions in a special note block of the trainee teacher. During the student teaching, each trainee teacher is followed by the teacher coach, counsellor and the internship coordinator. The workshop takes place during two semesters: semester 5 (S5) and semester 6 (S6).

During this academic year, the trainee teacher must have 5 notes:

-continuous control in half 2-notes 5 (S5).

Table 1. Model of distribution of internship.

\begin{tabular}{|c|c|c|c|c|}
\hline & \multicolumn{2}{|c|}{ Tuesday } & \multicolumn{2}{|c|}{ Thursday } \\
\hline & $8 \mathrm{~h}$ to $10 \mathrm{~h}$ & $10 \mathrm{~h}$ to $12 \mathrm{~h}$ & $8 \mathrm{~h}$ to $10 \mathrm{~h}$ & $10 \mathrm{~h}$ to $12 \mathrm{~h}$ \\
\hline Student A & Teaching & Observation & - & - \\
\hline Student B & Observation & Teaching & - & - \\
\hline Student C & - & - & Teaching & Observation \\
\hline Student D & - & - & Observation & Teaching \\
\hline
\end{tabular}


-continuous control in half 2-notes 6 (S6).

-A note of final examination at the end of the year.

These continuous control notes are 30 rating materials and final test score represents 70 of note. The absence during the internship period is strictly prohibited whatever the circumstances and each absence must be justified by an exhibit of the director of studies or the coordinator of student teaching.

\section{Methodology}

In our study, it used the questionnaire for teachers. In addition, asked the opinion of pedagogical advisors concerning the skills necessary for teaching from maintenance.

\subsection{Questionnaire}

The questionnaire is an instrument consisting of a series of questions to collect information from respondents. Perrault (2010) constructed its own tool to evaluate the effectiveness of training. This tool is a satisfaction questionnaire that addresses issues relating to the acquisition of skills necessary for teaching. This tool rotates on 10 skills which are respectively: Act in official State and an ethical and responsible way, mastering French to teach and communicate, mastering disciplines and have a good general culture, design and implement his teaching and organising the work of the class, take into account the diversity of students, evaluating students, master the technologies of information and communication work in team and cooperate with parents and school partners, develop and innovate. The answers to these questions are very interesting because they allow enjoying a clear idea about the efficiency of the training, which should improve the gaps and strengthen the qualities. According to the methodology of investigation developed by Gérard (2003) to assess the effectiveness of training, self-assessment of mastery of the competencies of respondent is to estimate its level of efficiency on a scale to 8 boxes ranging from "not at all effective" to "quite effective" for each of academic skills, the heart of business and cross before and after training. 10 skills using a scale of assessment of training have been built. The scale consists of 33 statements where the teacher is called to express its views on a Likert scale ranging from $1=$ completely disagree, to (quite agree) 8 (see Annexes). After the establishment of the questionnaire and before the launch of the survey sample, was a pre-test. Our first concern in the pre test was to ensure as far as possible the good understanding of the issues by the interviewees. Also, we have applied this test on a sample reduced in the universe of the investigation, but which is not part of the sample extract and having the same characteristics as the study population overall. In this questionnaire, we took into consideration the comments of teachers and subsequently we have changed a few expressions of some questions so that they correspond to the direction of our research.

\subsubsection{Data Collection}

The distribution of the questionnaires will be held during the month of may, 2014 and may 2015 at the Sfax ISSEP. Questionnaires were distributed to students in 3rd year license during the free time of course. In addition we took care to explain a few items to help respondents to choose the answer that suits them.

\subsubsection{Study Population}

Each student in 3rd year Bachelor EPS must perform a teaching internship of teaching of EPS in a primary school, a preparatory school or in a school of a session per week (Tuesdays and Thursdays) during the entire school year. Our population is composed of. Our sample consists of 402 trainee teachers of the higher Institute of sport and physical education of Sfax who participated voluntarily in this study after an eight month internship in different schools of the city of Sfax.

Study population is composed of 10 counsellors among 19 as in Table 2.

\subsubsection{Statistical Analysis of the Data}

For the treatment of response, the statistical analysis is performed on a micro-computer using software "excel".

\section{Table 2. Model of distribution of internship.}

\begin{tabular}{cccc}
\hline & $\mathrm{M}$ & $\mathrm{F}$ & Total \\
\hline The pedagogical advisor & $\mathrm{N}=229$ & $\mathrm{~N}=173$ & $\mathrm{~N}=402$
\end{tabular}


All statistics are regarded as significant for a threshold of probability less than 0.05 .

Homogeneity:

Homogeneity or the coefficient of variation is an index which measures the dispersion of the data about the mean relatively. It is calculated as a ratio sex educator percentage. This rate is a ratio between two scores: the standard deviation and the way

Homogeneity means deviation

According to HAINAUT (1975), the killer whale the percentage of homogeneity is:

-15 below, the uniformity is important.

-While above 30, homogeneity is weak.

According to Gerrard (2003) "his advantage over the standard deviation is given a percentage that allows to delete the reference to the average" according to OUELLET (1985). "The interest of this index is that it allows getting an idea of the level of agreement among the respondents." According to Gerrard (2003) "comparison of rate heterogeneity shows that the training helped reduce the disparity that existed at the outset, which means that learning has had an effect of 'fairness', insofar as differences in skills between the participants are reduced and that training has thus contributed to a larger" sharing "skills."

Average relative gain:

According to Gerard (2003), one can calculate the learning effect by calculating the index's gain on average. The treatment of this index for each objective to have a fairly fine estimate of the educational effectiveness of the training. According to Gerard (2003), the average relative gain is calculated by the following formula:

GRM (Score after-before Score) (MAXIMUM Score-Score before) $\times 100$

One can consider a positive learning effect when this relative gain exceeds 40 .

\subsection{The Maintenance}

Maintenance is a method of qualitative research typically used in scientific research in human and social sciences. According to Guitet (2008) 'maintenance is an indispensable research and information processing. Maintenance used in this research is directed semi maintenance. The latter represents a mixture between closed and open maintenance. Maintenance consists of 10 questions revolves around the 10 skills necessary for teaching.

\subsubsection{Maintenance Guide}

The guide is the set of specific instructions has each of servicing. Inspired by Guittet (2008) prepares a maintenance manual. Our maintenance guide contains the following steps:

-stand.

-present the framework of maintenance.

-present the objectives of maintenance.

-know the time to availability of counsel.

-give a 'check-List' of the essential points of maintenance.

-give an idea on the number of questions.

-estimate the duration of the maintenance.

\subsubsection{Content Analysis}

According to (Coffey Atkinson, 1996) Langley, 1997), there are several methods for the analysis of qualitative data. It is not a better than any other method. The choice of method depends on tradition in which the researcher works (Trudel Gilbert, 1999). After having made the transcription of responses (see Annexes) attempted to make the content analysis. We chose to do a manual scan method. This method is the analysis of manual content inspired by Philippe Wanlin (2007). This method is to do a reading of the interview responses and classify it according to specific themes. These themes are classified in a lexical field that is in relation with the skills necessary for teaching.

\section{Results}

\subsection{Questionnaire}

According to results in the Table 3, found that the rate of heterogeneity (coefficient of variation) increased after the H2 29.42 stage compared to baselines H1 21.78, but this rate remains above a 15 . This explains that the 
Table 3. Effect of learning (GRM) on competence 10 "form and innovate."

\begin{tabular}{ccccccccc}
\hline Competence & Date & \multicolumn{5}{c}{ Statistical analysis } \\
\hline & & Average & $\begin{array}{c}\text { Standard } \\
\text { deviation }\end{array}$ & CV & Error type & GBM & GRM \\
Competence 10: & & before & 4.46 & 1.31 & $29.42 \%$ & 0.065 & 1.33 & $37.71 \%$ \\
& After & 5.80 & 1.26 & $21.78 \%$ & 0.063 & & \\
\hline
\end{tabular}

student teaching PSE has failed to reduce the gap that existed at the beginning of the internship, which explains that learning did have an effect of "fairness", in other words, differences in levels skills among trainee teachers of EPS are not reduced later the student teaching of EPS has therefore not participated in a more 'sharing' skills. And after the results yet we notice that there is a positive learning effect (average relative gain) on the sense of self efficiency with a relative gain of GRM 37.71, but this rate remains insufficient since it is less than 40 . This indicates that trainee teachers of EPS did not consider having actually increased during the teaching course of EPS with regard to the jurisdiction to form and to innovate.

\subsection{Maintenance}

From above table attempts to identify lexical fields that are consistent with the 10 jurisdiction 'form and to innovate' which are essentially (form, to innovate, motivation, seminar, guide to intern, luggage, creativity, pedagogical days,...). The Figure 2 below represents the ideas that show the frequency of use of the lexical fields of expertise 10 during maintenance. According the results of the interview for pedagogical advisors, we note that there is a uniformity of response $(51,72)$ with regard to a lack of mastery of the tenth jurisdiction "form and to innovate". Thus the majority of pedagogical advisors believe that the trainee teacher from EPS to do not master this skill after the educational stage and later stage has not allowed a good mastery of this skill.

\section{Discussion}

This study was to search the effect of student teaching on the feeling of skills "to form and to innovate". The results of this study show the absence of positive learning effect in the sense of self efficiency with a relative gain of GRM 37.71, but this rate remains insufficient since it is less than 40. This indicates that trainee teachers of EPS did not consider having actually increased during the teaching course of EPS with regard to jurisdiction form and innovation. This is consistent with studies of Mukamurera (2002) and Leveille and Dufour (1999), which shows that "development plans or strategies for educational innovation found difficulties" (Mukamurera, 2002; Léveillé and Dufour, 1999). This result could also be explained by the fact that teachers in their early career usually opted for "compliance" strategies to "ensure their survival" (Blanchette, 2007: p. 57). According to the OECD, "the school and the courses too often tend to be disconnected from the developments in society" In addition, according to so-called Fourgous (2012), "rare are teachers who innovate in their practices, allow the student to become a creator and producer of content". According to the results of the interview for pedagogical advisors, we note that there is a uniformity of response with regard to a lack of mastery of the tenth jurisdiction "to form and to innovate". Thus the majority of pedagogical advisors believe that the trainee teachers from EPS do not master this skill after the educational stage and later stage has not allowed a good mastery of this skill. So we have similar opinions between the trainee teacher and counsellor in what regards powers "form and innovate", which reinforces our result.

The contributions of this study reflect on several fronts:

-First, at the level of the originality of the research: the feeling of competence (detailed in different type of jurisdiction) is a concept that is not investigated in the context of the teaching of physical education including the teaching course of EPS.

-Then this type of evaluation of student teaching of EPS by jurisdiction "allows to have a quite fine appreciation of the pedagogical effectiveness of training, including by highlighting the objectives which would be not sufficiently controlled and for which additional training would be necessary" (Gerard, 2003: p. 57).

-Finally, for the use of a reliable and credible assessment in the teaching field, according to Gerard (2003), this tool "is used currently with many benefits in many formations either in teaching of the IUFM research centres or companies... as well as advisors in pedagogy University of the IPM (Institut de pédagogie universitaire et 


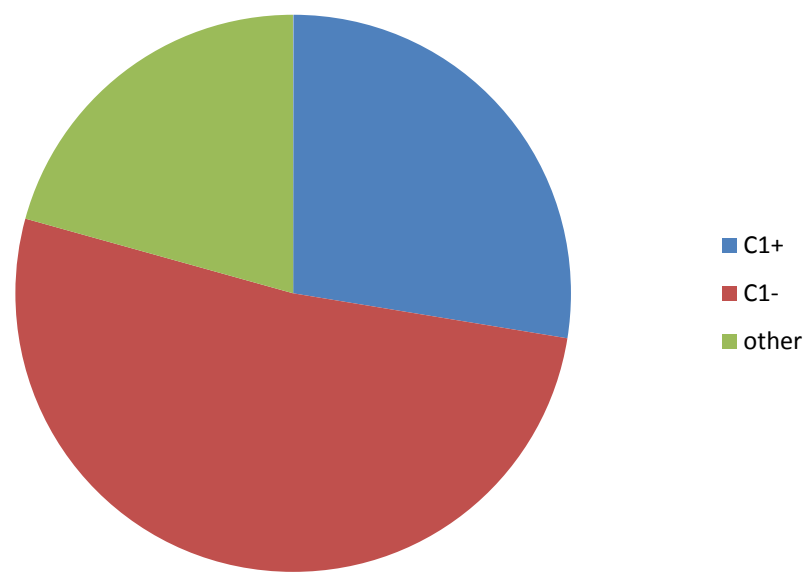

Figure 2. breakdown of responses of maintenance on competence 10 "form and to innovate."

multimedia) as part of the formative evaluation of the academic policy" (GÉRARD, 2003: p.5).

While measuring the interest of our research can recognize some limitations:

-Firstly, the search is limited regionally (region of Sfax) with a heterogeneous Tunisian population which is characterized by the existence of subcultures and different social classes.

Besides, the identity discomfort affecting the teaching realm is not an inconsiderable difficulty for the researcher in his investigation of the manner in which practitioners look back at their actions with a critical eye (Jorro, 2005). This could cause a kind of subjectivity in the assessment of the training.

Finally, trainee teachers might ignore the advice of the counselor teacher who provides permanent training, unlike the adviser teacher.

For all these reasons, it is concluded that our research opens many perspectives:

First, expand research in all institutes of sport of Tunisia (ISSEP Ksar Saïd, ISSEP Gafsa and ISSEP Kef) with these different subcultures to make the project a national project.

Then organizing scientific seminars and congresses on teaching can encourage trainee teachers to enhance development and innovation in the fields of teaching and pedagogy.

Then, the return of the TEPS in physical education for greater consolidation of the educational knowledge consolidates the educational knowledge in physical education of teacher trainees.

Finally, recommend further research to explain why trainee teachers failed in the "develop and innovate" jurisdiction. According to the European Commission (2010), "it is necessary to consider an innovative teaching, which is certainly not looking to the past" (European commission, 2010: p.331).

\section{References}

Blanchette, S. (2007). Strengthening Professional Autonomy in Early Career.

Bourdoncle, R. (2000). Around the Words: Professionalization, Forms and Devices. Research and Training, 35, 117-132.

Bouvier, B. (2008). Interpretative Frameworks Mobilized by the Educational Advisor to Analyze the Situations of TeachingLearning in EPS.

Carlier, G. (2002). Supervise Interns in Physical Education: Tags for a Function in the Process of Professionalization. Avante, 8, 96-111. http://dial.uclouvain.be/vital/access/manager/Repository/boreal:77697?site name=UCL

Carlier, G. (2009). Accompany and Form Masters of Internship in Physical Education. The Experience of the Catholic University of Louvain (Belgium). Éducation et Francophonie, 37, 68-88.

https:/www.google.tn/url?sa=t\&rct=j\&q=\&esrc=s\&source=web\&cd=1\&cad=rja\&uact=8\&ved=0ahUKEwiG8ZDOuML MAhV-BoRQKHblaAcQQFggZMAA\&url=https\%3A\%2F\%2Fwww.erudit.org\%2Frevue $\% 2 F e f \% 2 F 2009 \% 2 F v 37 \% 2 F n$ 1\%2F037653ar.pdf\&usg=AFQjCNFQRdQDilsxrbbjaWWk-NSGWEb6jg\&sig2=VtuYkFmn-Tb8EQn0vuhBSQ\&bvm=bv 121099550, d.d24

Dugal, J.-P., \& Amade-Escot, C. (2004). Council Training and Professional Development of Pedagogical Advisors: Research Cooperative and Didactic Knowledge. Research and Training, 46, 97-116.

http://ife.ens-lyon.fr/publications/edition-electronique/recherche-et-formation/RR046-07.pdf 
Greenhouses, G. (2009). Analysis of the Activity of Supervision with Regard to Its Effects on the Trajectories of Training of Trainee Teachers. Éducation et francophonie, 37, 107-120. https://halshs.archives-ouvertes.fr/hal-00871700/document

Lacoste, J. P. et al. (2007). The Internship in Responsibility in the Initial Training of Teachers. Ministry of National education, Higher Education and Research, p. 7. http://www.education.gouv.fr/archives/2012/refondonslecole/wp-content/uploads/2012/07/rapport igen igaenr le stage en responsabilite dans la formation initiale des enseignants mars 2007

Lessard, C., \& Bourdoncle, R. (2002). What Is Academic Training? Conceptions of University and Vocational Training. Revue française de Pédagogie, 139, 131-154. http://ife.ens-lyon.fr/publications/edition-electronique/revue-francaise-de-pedagogie/INRP_RF139 10.pdf

Men (2010) Missions of the Professors Counsellors at Secondary Schools Contributing to the Training of Trainee Teachers (Circular no. 2010-103, 13 July). http://www.education.gouv.fr/cid52621/mene1013096c.html

Perrault, B. (2008). Evaluating Training by Trainees of the First and Second Degrees in IUFM Training. A Survey of Trainees from the IUFM. 26-28.

http://www.Univ-Reims.frformationufr-Instituts-et-ecolesl-IUFM-champagne-ardenneformationobservatoire-desformation sgalleryfilessite19044011572515730.pdf

Perrault, B. (2010). The Sense of Personal Effectiveness as an Indicator of the Effectiveness of Training. An Application Is the Evaluation of the Training of the Teachers Acts of the Congress of the Topicality of the Research. https://plone.unige.ch/aref2010/communications-orales/premiers-auteurs-en-p/Le $\% 20$ sentiment $\% 20 \mathrm{defficacite.pdf}$

Romano, J. L. (1996). School Personnel Prevention Training: A Measure of Self-Efficacy. The Journal of Educational Research, 90, 57-63.

https://experts.umn.edu/en/publications/school-personnel-prevention-training(2799dbd5-477a-489d-a56e-32a7cf7eb7df).h $\underline{\mathrm{tml}}$

Tremblay, E. (2013). Design Students in Initial Teacher Training for the Role of University Trainers in Their Use of Pedagogical Approaches Diversified Training. Unpublished Master's Thesis, Montréal: Université du Québec à Montréal. http://www.archipel.uqam.ca/6266/1/M12974.pdf

Tremblay, E. et al. (2015) The Use of Types of Education Stage by Future Teachers in Pre-School Education and Primary Education. Canadian Journal of Young Researchers and Researchers in Education, 6, 55-67. 


\section{Annexes}

Scale of measure of efficacy of trainee teachers.

As part of research on the sense of personal effectiveness as an indicator of the effectiveness of student teaching of EPS, please complete this questionnaire. You check the boxes provided for this purpose and corresponding to your point of view on the issue.

Thank you for your collaboration.

Institution:

Sexe:

Age:

\begin{tabular}{|c|c|c|c|c|c|c|c|c|c|c|c|c|c|c|c|c|c|}
\hline \multirow{2}{*}{\multicolumn{2}{|c|}{$\begin{array}{l}\text { You are asked to estimate your level of efficacy } \\
\text { for each of the mentioned skills before and after } \\
\text { the year of internship training. }\end{array}$}} & \multicolumn{8}{|c|}{ Pre-internship } & \multicolumn{8}{|c|}{ After the internship } \\
\hline & & \multicolumn{4}{|c|}{$\begin{array}{l}\text { not everything has } \\
\text { been able }\end{array}$} & \multicolumn{4}{|c|}{$\begin{array}{l}\text { Any fact at } \\
\text { able }\end{array}$} & \multicolumn{3}{|c|}{$\begin{array}{l}\text { not everything } \\
\text { has been able }\end{array}$} & \multicolumn{5}{|c|}{ Any fact at able } \\
\hline 1 & $\begin{array}{l}\text { control the disciplinary knowledge } \\
\text { necessary to teach }\end{array}$ & 1 & 2 & 3 & 4 & 5 & 6 & 7 & 8 & 1 & 2 & 3 & 4 & 5 & 6 & 7 & 8 \\
\hline 2 & $\begin{array}{l}\text { identify links between the disciplines to } \\
\text { contribute to their articulation }\end{array}$ & 1 & 2 & 3 & 4 & 5 & 6 & 7 & 8 & 1 & 2 & 3 & 4 & 5 & 6 & 7 & 8 \\
\hline 3 & $\begin{array}{l}\text { identify and appeal to those who can } \\
\text { provide help and support in exercise of the } \\
\text { profession. }\end{array}$ & 1 & 2 & 3 & 4 & 5 & 6 & 7 & 8 & 1 & 2 & 3 & 4 & 5 & 6 & 7 & 8 \\
\hline 4 & $\begin{array}{l}\text { enter the value of the Tunisian Republic in } \\
\text { his professional practice (fight against } \\
\text { discrimination, equal opportunities... ...) }\end{array}$ & 1 & 2 & 3 & 4 & 5 & 6 & 7 & 8 & 1 & 2 & 3 & 4 & 5 & 6 & 7 & 8 \\
\hline 5 & $\begin{array}{l}\text { take into account in his teaching the } \\
\text { contributions of school and teaching } \\
\text { research. }\end{array}$ & 1 & 2 & 3 & 4 & 5 & 6 & 7 & 8 & 1 & 2 & 3 & 4 & 5 & 6 & 7 & 8 \\
\hline 6 & $\begin{array}{l}\text { Act on a daily basis in its class in } \\
\text { compliance with the Regulation (rights, } \\
\text { duties of officials, official texts). }\end{array}$ & 1 & 2 & 3 & 4 & 5 & 6 & 7 & 8 & 1 & 2 & 3 & 4 & 5 & 6 & 7 & 8 \\
\hline 7 & $\begin{array}{l}\text { be careful to the quality of the language } \\
\text { among students. }\end{array}$ & 1 & 2 & 3 & 4 & 5 & 6 & 7 & 8 & 1 & 2 & 3 & 4 & 5 & 6 & 7 & 8 \\
\hline 8 & analyze its business practices. & 1 & 2 & 3 & 4 & 5 & 6 & 7 & 8 & 1 & 2 & 3 & 4 & 5 & 6 & 7 & 8 \\
\hline 9 & formulating its vocational training needs. & 1 & 2 & 3 & 4 & 5 & 6 & 7 & 8 & 1 & 2 & 3 & 4 & 5 & 6 & 7 & 8 \\
\hline 10 & $\begin{array}{l}\text { integrate in its practices } 107 \text { (a) of the } \\
\text { mastery of oral and written language } \\
\text { activities by students }\end{array}$ & 1 & 2 & 3 & 4 & 5 & 6 & 7 & 8 & 1 & 2 & 3 & 4 & 5 & 6 & 7 & 8 \\
\hline 11 & being exemplary in its use of language. & 1 & 2 & 3 & 4 & 5 & 6 & 7 & 8 & 1 & 2 & 3 & 4 & 5 & 6 & 7 & 8 \\
\hline 12 & $\begin{array}{l}\text { Ensure a framework guaranteeing the } \\
\text { safety, security and respect for all students } \\
\text { (integrities physical and moral of the } \\
\text { students, sanction, authority, justice...) }\end{array}$ & 1 & 2 & 3 & 4 & 5 & 6 & 7 & 8 & 1 & 2 & 3 & 4 & 5 & 6 & 7 & 8 \\
\hline 13 & build a progression of learning & 1 & 2 & 3 & 4 & 5 & 6 & 7 & 8 & 1 & 2 & 3 & 4 & 5 & 6 & 7 & 8 \\
\hline 14 & $\begin{array}{l}\text { use tic (information and communication } \\
\text { technology) for networking with colleagues } \\
\text { ("facebook" social networks, e-mail, } \\
\text { forum...) }\end{array}$ & 1 & 2 & 3 & 4 & 5 & 6 & 7 & 8 & 1 & 2 & 3 & 4 & 5 & 6 & 7 & 8 \\
\hline 15 & $\begin{array}{l}\text { analyze the observed performance and } \\
\text { determine the causes of errors }\end{array}$ & 1 & 2 & 3 & 4 & 5 & 6 & 7 & 8 & 1 & 2 & 3 & 4 & 5 & 6 & 7 & 8 \\
\hline 16 & $\begin{array}{l}\text { teaching with reference to the objectives } \\
\text { and content of formal programs of EPS. }\end{array}$ & 1 & 2 & 3 & 4 & 5 & 6 & 7 & 8 & 1 & 2 & 3 & 4 & 5 & 6 & 7 & 8 \\
\hline 17 & $\begin{array}{l}\text { integrate ICT ((technologie d'information } \\
\text { et de communication) in sessions with } \\
\text { students) }\end{array}$ & 1 & 2 & 3 & 4 & 5 & 6 & 7 & 8 & 1 & 2 & 3 & 4 & 5 & 6 & 7 & 8 \\
\hline 18 & $\begin{array}{l}\text { organize situations learning developing } \\
\text { participation and cooperation among } \\
\text { students }\end{array}$ & 1 & 2 & 3 & 4 & 5 & 6 & 7 & 8 & 1 & 2 & 3 & 4 & 5 & 6 & 7 & 8 \\
\hline
\end{tabular}




\section{Continued}

create a climate of confidence (attitude,

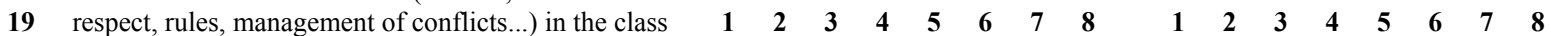
supported learning

choose pedagogic and didactic means

20 (group work, media,...) adapted to the learning objectives

to evaluate the skills of the common-base (the

21 common base of knowledge and skills this what all students should know and master at the end of compulsory schooling)

22 adapt the conduct of the meeting on the basis of the effective work of the students

design at the different times of learning

23 assessment to make account of student assessment

24 build learning situations based on skills to provide skills to students

25 use ICT (information and communication technology) to update his knowledge and develop

26 choose teaching situations that involve students in learning

27 differentiate his practice according to the needs of students

Build relationships with external partners (sporting,

28 artistic or cultural projects, relations with the professional world...)

29 Develop with colleagues from projects in the school or the establishment

30 Being able to integrate students with special needs or with disabilities

31 Dialogue with the parents or families on his teaching and on the monitoring of students Ensure follow-up etou orientation of students in

32 collaboration with relevant institutional partners (counselling, medical-social services, protection of childhood...)

33 Adapt the content of the meeting so as to

$\begin{array}{lllllllllllllllll}1 & 2 & 3 & 4 & 5 & 6 & 7 & 8 & & 1 & 2 & 3 & 4 & 5 & 6 & 7 & 8\end{array}$

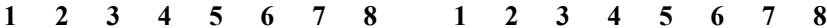

$\begin{array}{lllllllllllllllll}1 & 2 & 3 & 4 & 5 & 6 & 7 & 8 & & 1 & 2 & 3 & 4 & 5 & 6 & 7 & 8\end{array}$

$\begin{array}{llllllllllllllll}1 & 2 & 3 & 4 & 5 & 6 & 7 & 8 & 1 & 2 & 3 & 4 & 5 & 6 & 7 & 8\end{array}$

$\begin{array}{lllllllllllllllll}1 & 2 & 3 & 4 & 5 & 6 & 7 & 8 & & 1 & 2 & 3 & 4 & 5 & 6 & 7 & 8\end{array}$

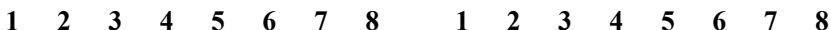

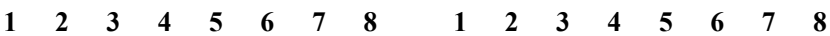

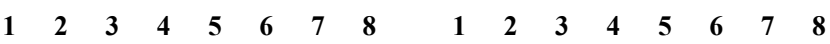

$\begin{array}{llllllllllllllll}1 & 2 & 3 & 4 & 5 & 6 & 7 & 8 & 1 & 2 & 3 & 4 & 5 & 6 & 7 & 8\end{array}$

$\begin{array}{lllllllllllllllll}1 & 2 & 3 & 4 & 5 & 6 & 7 & 8 & & 1 & 2 & 3 & 4 & 5 & 6 & 7 & 8\end{array}$

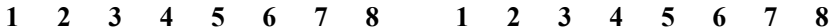

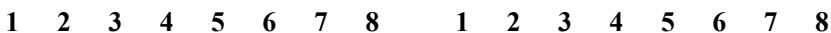

$\begin{array}{lllllllllllllllll}1 & 2 & 3 & 4 & 5 & 6 & 7 & 8 & & 1 & 2 & 3 & 4 & 5 & 6 & 7 & 8\end{array}$

$\begin{array}{lllllllllllllllll}1 & 2 & 3 & 4 & 5 & 6 & 7 & 8 & & 1 & 2 & 3 & 4 & 5 & 6 & 7 & 8\end{array}$ 